\title{
Free Movement and EU Citizenship from the Perspective of Intra-European Mobility
}

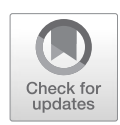

\author{
Saara Koikkalainen
}

In his kick-off text, Floris de Witte argues that the value of free movement lies in its capacity to emancipate the individual from the nation state, to recalibrate questions of justice and democracy, and to sever ties to a homogenous political 'community of fate'. My contribution builds on empirical research on intra-European mobility and elaborates on his first claim on emancipation. I offer two factors to support my interpretation of the strong link between free movement and EU citizenship: 1) the development of the very concept of European citizenship is at least partly the result of a longer history of free movement and 2) the concrete advantages of EU citizenship are strongly linked to free movement. I finish with the conclusion that free movement makes the EU real also for those Europeans who have not exercised their right to move. As de Witte says: 'Freedom of movement, in other words, liberates not only the body but also the mind from the normative structures of the state.'

\section{The history of free movement and EU citizenship}

The foundations of free movement date back to the 1950s and the Treaty establishing the European Coal and Steel Community (ECSC), where the cross-border movement of coal and steel industry workers was to be eased to aid the growing post-war economies. The EEC-Treaty extended free movement rights to workers in other industries, with the exception of the public sector, and these rights were codified in 1968 for the workers from the six original Member States. Since the 1970s, the European Court of Justice has played a fundamental role in widening the scope of free movement, as ordinary Europeans have been active in testing its boundaries in court, thus gradually extending the right of free movement to persons. The process culminated with the introduction of European citizenship in the Maastricht Treaty in 1992 where the right was extended to citizens. ${ }^{1}$

e.g. Koikkalainen, S. (2011), Free movement in Europe: Past and Present. Migration Information Source. Washington, DC: Migration Policy Institute, available at www.migrationinformation.org/Feature/display.cfm?ID=836.

(C) The Author(s) 2019 
While free movement was originally based on an economic rationale and the desire to provide a flexible workforce for the industry, it has developed into a civic right that might have been impossible to envision without the preceding decades of mobility. The right is also highly valued by the Europeans themselves: in the Eurobarometer surveys, ${ }^{2}$ freedom of movement consistently ranks high among the things that Europeans value in the EU. In the autumn of 2015,78 per cent of the respondents supported free movement, even though differences among countries were significant (94 per cent support in Latvia and 92 per cent in Estonia, while only 64 per cent in the UK and 66 per cent in Austria). Free movement is also routinely listed as the most positive or the second most positive result of the EU along with 'peace among the EU member states'. Therefore, while issues such as access to social security and transferability of pensions across borders are still problematic, it is clear that free movement is, according to the Europeans themselves, at the core of European citizenship.

\section{The value of EU citizenship is linked with free movement}

Europeans take advantage of free movement as students, trainees, professionals, family members, retirees, and workers of different skills and educational backgrounds. Not all are moving for life, as many choose to live abroad temporarily or seasonally or engage in various cross-border activities. $^{3}$ In response to de Witte, Daniel Thym writes that while he understands the value of free movement for the individual, he also sees the limitations of de Witte's argument: 'European rules extend our freedom geographically and in substance, but the surplus remains gradual instead of categorical.' Thym downplays the exceptionality of a situation where a German pensioner, for example, is free to settle in Spain, instead of just relocating to a more pleasant environment within Germany. However, along with others engaged in research in intra-European mobility, I argue that those who exercise their right to free movement are pioneers of European integration, whose lives and actions impact both the countries of origin and

2 Standard Eurobarometer 84, 2015, EC, DG for Communication. First results (Autumn 2015).

3 E.g. Favell, A. (2008), Eurostars and Eurocities: Free Movement and Mobility in an Integrating Europe. Oxford: Blackwell; King, R. (2002), 'Towards a new map of European migration', International Journal of Population Geography 8 (2): 89-106. DOI: 10.1002/ijpg.246; Recchi, E. (ed.) (2014), The Europeanisation of Everyday Life: Cross-Border Practices and Transnational Identifications among EU and Third-Country Citizens - Final Report. Available at http://nbn-resolving.de/urn:nbn:de:0168-ssoar-395269 . 
destination as well as the socio-cultural construction of Europe in a multitude of different ways. ${ }^{4}$

In Richard Bellamy's view, EU citizenship does not undermine national citizenship but rather defends it in the 'context of the normative and empirical challenges of an inter-dependent world.' Yet when examining EU citizenship from the viewpoint of the intra-European migrant, I am tempted to agree with de Witte that it is 'distinct from, and genuinely supplementary to, national citizenship'. Namely, the extensive rights granted by EU citizenship have made adopting the (legal) citizenship of the country of destination largely unnecessary, and for Europeans the value of citizenship acquisition is clearly lower than for third-country nationals wishing to legally settle within the EU. In 2013, for example, in twelve EU member states at least nine out of ten persons who were granted citizenship were non-EU citizens while only in Hungary and Luxembourg EU-migrants were in the majority. ${ }^{5}$ There is hardly any other circumstance where EU citizenship would have such a manifest impact on the lived experience of an individual than the possibility of being a legal, long-term resident of a country with minimal pressures to naturalisation.

\section{Imaginary horizons and cognitive migration}

Free movement is at the core of EU citizenship also because it opens horizons for Europeans who have not moved abroad, but may have seriously considered the matter, plan to do so in the future or see mobility as an option for their children. The imagination of a potential future involving international migration is a way of making Europe or the EU seem real in the mind of an individual. ${ }^{6}$ It relies on a process we have called cognitive migration where the mind may travel multiple times before the actual bodily move takes place. ${ }^{7}$ In the Flash Eurobarometer of spring 2016 four in five respondents were aware of their mobility rights as European citizens, ${ }^{8}$ so the option

4 Recchi, E. and Favell, A. (eds.) (2009), Pioneers of European integration. Citizenship and mobility in the EU. Cheltenham: Edward Elgar.

5 Eurostat (2015), Acquisition of citizenship statistics. Eurostat Statics

Explained. Available at http://ec.europa.eu/eurostat/statistics-explained/index. php/Acquisition_of_citizenship_statistics

6 Castano, E. (2004), 'European identity: A social-psychological perspective', in R.K. Herrmann, T. Risse \& M.B. Brewer (eds.), Transnational identities:

Becoming European in the EU, 40-58. Oxford: Rowman \& Littlefield.

7 Koikkalainen, S. \& Kyle, D. (2015), 'Imagining Mobility: The Prospective Cognition Question in Migration Research', Journal of Ethnic and Migration Studies 42 (5): 759-776, doi: 10.1080/1369183X.2015.1111133.

8 Flash Eurobarometer 430 2016, EC, DG for Justice and Consumers \& DG for Communication. 
is widely known among ordinary Europeans. The impact of such a high share of individuals potentially imagining futures that transcend national borders should not be underestimated as a factor influencing what EU citizenship currently is and what it will be in the future.

Open Access This chapter is licensed under the terms of the Creative Commons Attribution 4.0 International License (http://creativecommons.org/licenses/by/4.0/), which permits use, sharing, adaptation, distribution and reproduction in any medium or format, as long as you give appropriate credit to the original author(s) and the source, provide a link to the Creative Commons license and indicate if changes were made.

The images or other third party material in this chapter are included in the chapter's Creative Commons license, unless indicated otherwise in a credit line to the material. If material is not included in the chapter's Creative Commons license and your intended use is not permitted by statutory regulation or exceeds the permitted use, you will need to obtain permission directly from the copyright holder.

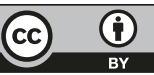

